\title{
LITERATURA
}

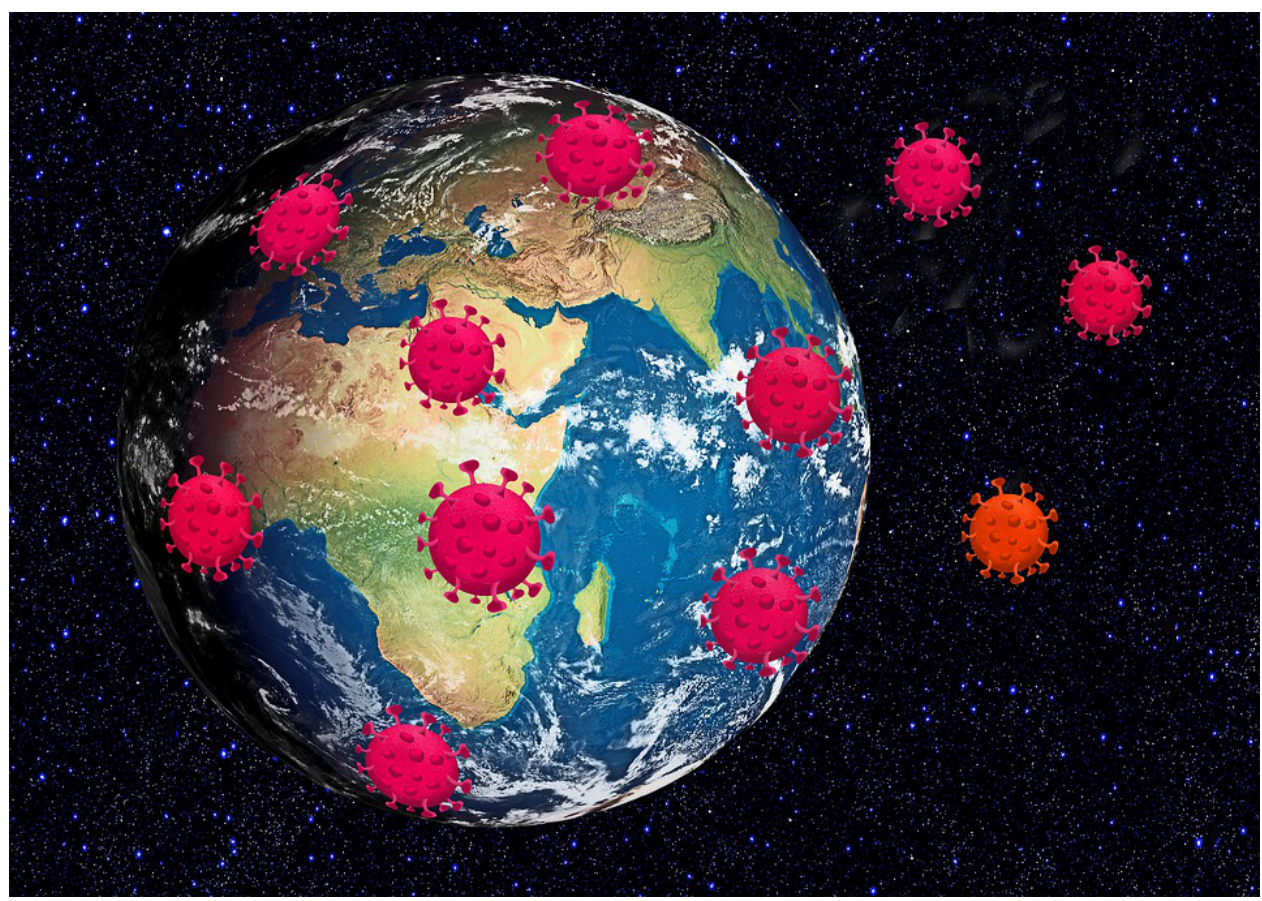

\section{Echándonos la suerte (Cara o sello) en tiempos de pandemia}

En estos días, no sale el sol sino tu rostro.

En tiempos de pandemia en Tacna o en Manchester, del sur del Perú al norte de Inglaterra puntual en su castigo central y coronado, virus diario, preside, ávido y hemisférico infame fiesta, cotidiano banquete de muertos.

Demente, medio ilustrado, aprendiz de Quijote, enfrentas huraña la página minotauro, te miras en el espejo, 
ojo en blanco

lames tu diaria derrota

inútil poeta,

marchada tu musa,

descubres nuevos linderos,

transcribes los hostiles versos

que tu sombra

avezada te dicta:

El cautiverio, la reclusión

no cansan,

solo iluminan el camino

el retorno, no al verde regazo,

sino a la vergüenza,

al fastidio

de no haber escrito

con más dosis de lujuria,

tildando el verso exacto y sagaz,

atizando

el pavor rojizo del alma, empuñando a gritos,

las rosadas aristas del corazón.

Lo sabemos:

ya no quedan certezas

solo lo irrevocable es real,

y la sorpresa que nos depara

lo que es: lo inevitable.

Enceldado y sin escapatoria

chacales de la pandemia:

en Manchester, en Tacna,

en Paris o Sao Paulo,

Nueva York y Madrid,

franquean las esquinas,

$\mathrm{y}$ todos nosotros

vamos en el mismo camino

arrastrando los mismos pesares,

que la pandemia escoge para nosotros;

con los mismos dolores y miedos,

marchamos

encadenados en el coro,

el abismo como horizonte,

compilamos, elegimos

las preciadas acuarelas

los recuerdos

de nuestras cortas vidas,

mientras los faroles alumbran, 
anuncian el siempre conocido, inexorable final.

Solitario, aprendiz de lobo registro el inicio exploro el último acto $\mathrm{y}$ en la noche final y perpetua, suelto y libre ya de tu mirada, ensayo mi cansado canto y con el último aliento, busco, y acaso encuentro la mano de algún dios que me espera, agotado y conmovido, veré por fin la rosa que ahora bosquejo para ti; y entre la ráfaga de violines, cansado, me dormiré con el inacabado verso manchado con tinta azul, tal vez leído ahora, (labios de alma generosa que me salvará del olvido) y así, sin protestas, moriré, en el lado equivocado del charco dejando lo que no tuve, desnudo en el lamento de no haber alcanzado Ítaca, digna y verde, Tarata tierna y única en la emoción final que conjura el último adiós.

Por ahora, todavía vivo, cuando la primavera europea se anuncia, entrando tibia en mis mañanas, coloreando lúcidos tulipanes; mientras respiro al mismo filo del abismo atento al diario conteo, al nefasto cortejo, la pandemia, sus ganancias sus negocios del día.

Hago cuenta entonces de otra urgencia final que necesito atender (y entender): encargo mis ansias al río de la suerte examino la prognosis de esta desdicha: 


\section{lanzo}

la gastada moneda al aire:

el destino,

hermoso y cruel a la vez,

se mostrará

en uno

de los excluyentes resultados:

cara, es decir, la vida, tu vida,

o sello, el olvido, el sello de mi muerte.

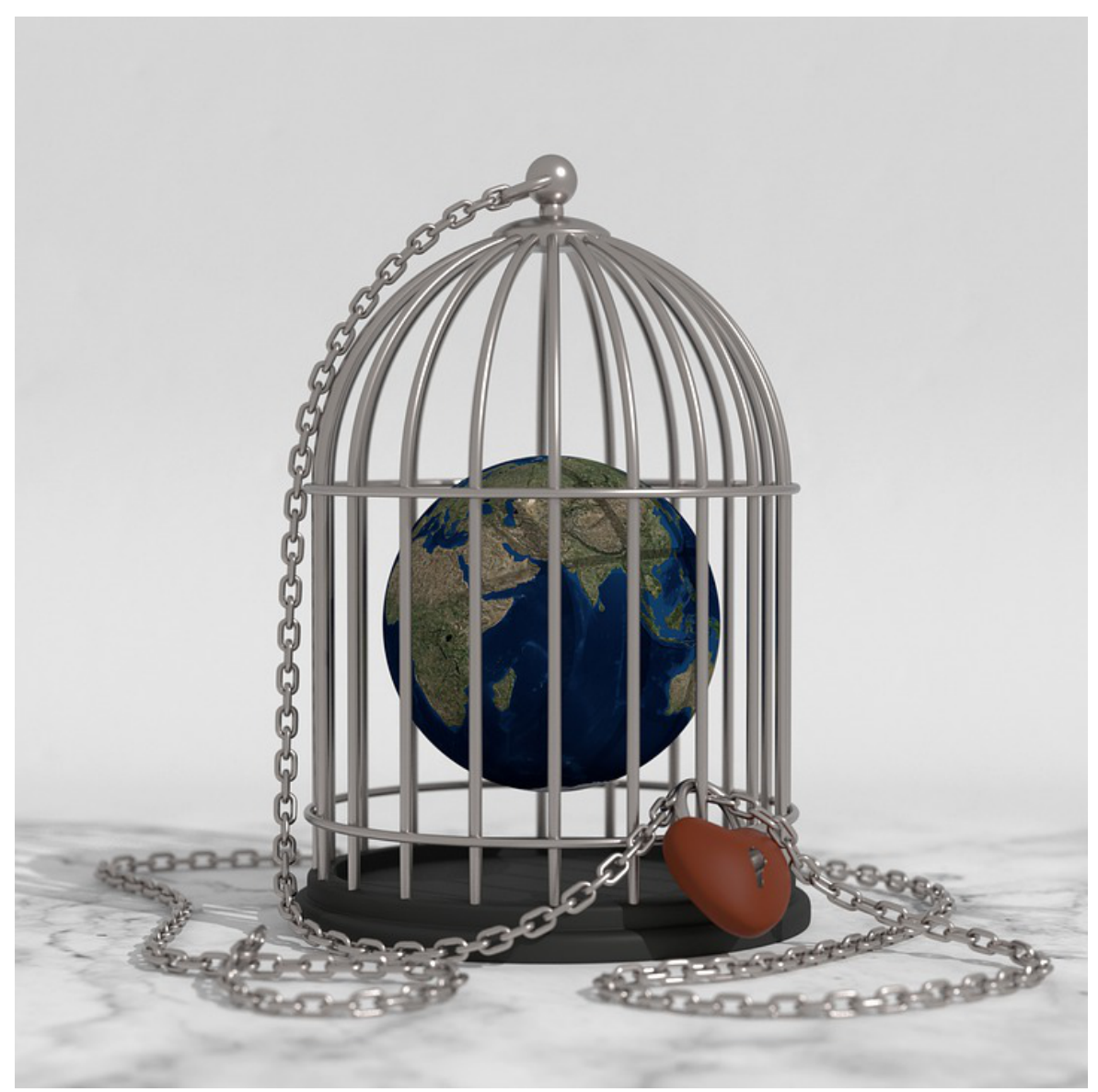

\section{Nota:}

Las ilustraciones corresponden a https://pixabay.com 